\title{
High-altitude migration of Psylloidea (Hemiptera) over England
}

\author{
ALEXANDER F. C. GREENSLADE \\ Rothamsted Research, West Common, Harpenden, Hertfordshire AL5 2JQ, UK; \\ alex.greenslade@rothamsted.ac.uk
}

\author{
JASON W. CHAPMAN \\ Centre for Ecology and Conservation, and Environment and Sustainability Institute, \\ University of Exeter, Penryn, Cornwall TR10 9FE, UK; \\ and College of Plant Protection, Nanjing Agricultural University, Nanjing 210095, China.
}

DON R. REYNOLDS

Natural Resources Institute, University of Greenwich, Chatham, Kent ME4 4TB, UK; and Rothamsted Research, Harpenden, Hertfordshire AL5 2JQ, UK

D.Reynolds@greenwich.ac.uk

\begin{abstract}
Some species of psyllid (Hemiptera: Psylloidea) are known to make high-altitude windborne migrations, but compared with their sister superfamily, the Aphidoidea, our knowledge of these movements is rudimentary and unsystematised. Here we have extracted psyllid capture data from day and night aerial sampling carried out at a height of $200 \mathrm{~m}$ above ground at Cardington, Bedfordshire, UK, during summers between 1999 and 2007. These records were consolidated with high-altitude psyllid catches made over England during the 1930s and with some other trapping results from northwest Europe which were indicative of migration. Information on aerial densities, diel flight periodicity, and the sex-ratio of the aerial psyllid populations is presented. We also compared our results with those of a recent study which used the Rothamsted Insect Survey network of suction traps (sampling at a height of $12.2 \mathrm{~m}$ ); this provided confirmative evidence that the suction-traps were indeed detecting migrating psyllids. Finally, both aerial netting and suction trap data were used to tentatively interpret the seasonal timing of migrations in terms of the breeding/overwintering cycles of some common psyllid species.
\end{abstract}

Key words: Jumping plant lice, aerial trapping, windborne migration, flight, atmospheric transport, seasonal cycles.

\section{Introduction}

Psyllids or jumping plant-lice (Hemiptera: Psylloidea) are phloem-feeding Sternorrhyncha which are habitually highly host-specific and include species which are significant pests particularly of fruit and ornamental trees (Hodkinson, 2009; Percy, 2014; Greenslade et al., 2020). Damage to hosts can be due to feeding and excretions, or to the vectoring of plant pathogens (e.g. the bacterium causing Citrus Greening Disease). Some psyllid species appear to move over significant distances by means of windborne migration, as evidenced by their capture high in the air (Berland, 1935; Hardy \& Milne, 1938; Freeman, 1939, 1945; Glick, 1939, 1960; Glick \& Noble, 1961; White 1970, 1973, 1974; Chapman et al., 2004; Weidel, 2008, 2010), and over the seas, remote from land (Harrell \& Yoshimoto, 1964; Holzapfel \& Harrell, 1968; Hardy \& Cheng, 1986; Peck, 1994); see also Hodkinson's review (2009). Extensive day- and night-time sampling of the upper air (e.g. by Glick, 1939) indicates that 
psyllids are very largely daytime migrants, and Trioza urticae (Linnaeus, 1758), for example, shows a well-defined diel flight periodicity curve with a maximum around noon (Lewis \& Taylor, 1965). Thus, it is likely that psyllids make potentially long-distance migrations by utilising lift from turbulent convection (Wainwright et al., 2017) as in the related superfamily, the Aphidoidea.

Recently, Greenslade et al. (2020) published an analysis of British psyllid diversity and seasonal migration patterns, using the Rothamsted Insect Survey network of suction traps sampling at a height of $12.2 \mathrm{~m}$ in England and Scotland (plus a similar trap in Sweden). At least for aphids, trapping at this height largely samples migrant individuals and the sample is representative of the aerial population over a wide area (Taylor, 1974).

The paucity of information on psyllids migrating at altitude over the UK has encouraged us to document captures of these hemipterans from a height of $\sim 200 \mathrm{~m}$ above ground, made during eight seasons of sampling over southern England. We integrate these results with catch data from the earlier literature (Hardy \& Milne, 1938; Freeman 1939, 1945) which are indicative of high-altitude migratory activity in the British species of Psylloidea. The resulting picture, although still fragmentary, will advance our understanding of migratory propensities and seasonal movements in this understudied group of insects.

\section{Materials and Methods}

The aerial sampling methods have been described in detail elsewhere (Chapman et al., 2004; Reynolds, Nau \& Chapman 2013; Reynolds, Chapman \& Stewart 2017), so we provide a brief summary here. Insects flying at $c a .200 \mathrm{~m}$ above ground level (a.g.l.) were captured in a drogue net of 1-m diameter aperture suspended from a tethered helium-filled kite-balloon (kytoon) (Fig. 1). The sampling site, at Cardington Airfield $\left(52^{\circ} 06^{\prime} \mathrm{N}, 0^{\circ} 25^{\prime} \mathrm{W}\right)$, Bedfordshire, in southern England, is in an official aircraft exclusion zone, thus allowing balloon flying above the normal Civil Aviation Authority limit of $60 \mathrm{~m}$. Sampling was carried out over eight seasons (in 1999, 2000, and 2002-2007), in various months between May and early September, but mostly in July (Table 1). Kytoon flying was undertaken opportunistically, in fine weather when there was no significant risk of lightning, rain or very strong winds. Occasionally, winds at altitude were too weak (i.e. below $\sim 3 \mathrm{~m} / \mathrm{s}$ ) for efficient netting. Each $24-\mathrm{h}$ period was generally divided into: $1 \mathrm{~h}$ around dusk ( 21.00-22.00 h BST in July); night-time after the dusk period (various durations, occasionally until dawn); 'morning' (10.00-14:00 h), and afternoon (14:00-18:00 h). At the end of each sample period, a radio-controlled net closure device was used to close-off the end of the net, and the kytoon was winched down to near ground level. A detachable net bag containing the catch was unzipped from the end of the net and placed in a plastic killing bottle. The sampling period 'wind run' (in kilometres) was read off a meter suspended below the kytoon (Fig. 1); this measurement allowed an estimate of the airflow through the net, from which the aerial density of insects in each sample could be calculated. The catch was sorted and preserved in a mixture of $95 \%$ ethanol and 5\% glycerol. Psyllids in the samples were later identified by one of us (AFCG); see Greenslade et al. (2020) for the taxonomic works used.

\section{Results and Discussion}

During the eight seasons of sampling at $200 \mathrm{~m}$ a.g.l. at Cardington, a total of 490 psyllids were caught (Table 1). The great majority of these (451) comprised a grouping of Cacopsylla melanoneura (Foerster, 1848) and C. affinis (Löw, 1880) which were amalgamated because females of these species could not be reliably distinguished (Greenslade et al., 2020). 
However, judging by the males of the two species (190 C. melanoneura individuals to only two of $C$. affinis), it seems likely that the former species was highly dominant in the collections. The next most numerous species was Trioza urticae (L.) with 17 specimens, followed by Aphalara spp. and Cacopsylla pruni (Scopoli, 1763) with 5 specimens each.

Our catches at altitude were generally in accord with the results of the $12.2 \mathrm{~m}$ suction trapping in England (Greenslade et al., 2020) where the C. melanoneura/affinis group and $T$. urticae were respectively the first- and third-most numerous, respectively, in the year-long study. Trioza remota (Foerster), which was the second-most prevalent species in the $12.2 \mathrm{~m}$ suction traps, was not taken in our samples or those of Hardy \& Milne (1938) and Freeman $(1939,1945)$. However, peak numbers of T. remota in the suction traps occurred in November and December, which was outside the sampling period of the high-altitude studies.

A comparison of the aerial catches from the present study with those made in England in the 1930s by Hardy \& Milne (1938) and Freeman $(1939,1945)$ is shown in Table 2. The most striking feature of the early studies was the large number (173) of an Aphalara sp. caught by Freeman in his higher-level traps (54 and $84 \mathrm{~m}$ ) mostly in September.

\section{Aerial densities}

Considering sampling occasions when psyllids were actually caught, the aerial densities over the eight seasons at Cardington were of the order of one individual per $10^{4} \mathrm{cu} . \mathrm{m}$ (ranging between 0.26 and 2.20 per $10^{4} \mathrm{cu}$. $\mathrm{m}$; see Table 1 ). The highest densities recorded were 7.7 7.8 per $10^{4}$ cu. $\mathrm{m}$ in two samples taken in June 2005 when sizeable numbers of $C$.

melanoneura / affinis were flying. In comparison with other hemipteran groups sampled, the psyllid aerial densities were greater than densities of the Heteroptera $\left(\sim 0.3\right.$ per $\left.10^{4} \mathrm{cu} . \mathrm{m}\right)$ and Auchenorrhyncha $\left(\sim 0.5\right.$ per $10^{4}$ cu. m; Reynolds, Chapman \& Stewart 2017), but smaller than aphid densities recorded at altitude over Cardington $\left(\sim 5\right.$ per $10^{4} \mathrm{cu} . \mathrm{m}$; Berry \& Taylor, 1968; Johnson, 1969, fig. 105). Even so, it is clear that at periods of mass emigration (like the June samples mentioned above), psyllid densities can temporarily rival those of aphids at altitude. We also note the aforementioned large numbers of an Aphalara sp. recorded by Freeman (1945) near Grimsby, Lincolnshire, flying "in swarms" in the autumn.

\section{Percentage of the total insect catch}

In the aerial sampling by Hardy \& Milne (1938), Freeman $(1939,1945)$ and the present study, psyllids comprised about 1-3\% of the total number of insects captured (Table 2). Similarly, in aerial sampling by aircraft over Schleswig-Holstein, North Germany (Weidel, 2010) psyllids comprised $3 \%$ of the total catch.

\section{Diel flight periodicity}

Psyllids were generally caught at Cardington in the daytime sampling periods ( 77 samples containing a total of 458 individuals), with a few continuing into the dusk period (12 samples containing 32 individuals); they were not caught in the night samples, i.e. after about 22:00 $\mathrm{h}$.

\section{Sex-ratio}

Psyllids usually show sex-ratios of close to 1:1 on adult emergence, but in some species there are indications that females disperse further than males (Hodkinson, 2009). This seems to be the case in our Cacopsylla melanoneura / affinis samples, where there were 259 females to 192 males - a significant departure from a 1:1 ratio (chi-square goodness-of-fit $=9.9534, P=$ $0.001605)$.

\section{Migration distance}


Small insects, such as psyllids, starting to ascend under daytime convective conditions, will be borne upwards if they encounter an updraft. Attaining the $200 \mathrm{~m}$ sampling height (assuming an updraft vertical speed of $\sim 1 \mathrm{~m} / \mathrm{s}$ ) even if followed by an (unlikely) immediate descent would involve a flight time of several minutes during which, at the average horizontal wind speeds recorded when psyllids were flying $(\sim 5.8 \mathrm{~m} / \mathrm{s})$, would transport the migrants at least $2 \mathrm{~km}$. This distance is, of course, the absolute minimum; the presence of psyllids far from any possible sources (see Introduction) indicate much longer flights. For example, Hodkinson (1972) records psyllids including C. melanoneura, C. affinis and Trioza urticae, overwintering on pines in northern England about $13 \mathrm{~km}$ from their nearest host plants. Movement over at least tens of kilometres is indicated by the capture of psyllids at quite high altitudes. For example, Berland (1935) caught unidentified psyllids at heights between 500 and $2300 \mathrm{~m}$ near Paris, and Weidel (2010) caught Cacopsylla melaneura (the dominant species in our study) at heights up to $1520 \mathrm{~m}$ over Schleswig-Holstein.

Nonetheless, as pointed out by Chapman et al. (2004), the fact that psyllids comprised a very small proportion of the North Sea catches of Hardy \& Cheng (1986) suggest that this group is much less likely to make long distance flights in the UK compared to certain species of aphid. Sometimes aphids may continue flying after dark which can greatly increase migration distances (Wainwright, Reynolds \& Reynolds 2020), but our results indicate that night-time psyllid migration does not occur to any great extent in Britain (see above).

\section{Phenology and migration}

The Cacopsylla melanoneura / affinis group (mainly $C$. melanoneura judging by the tally of males) were caught between May and August, but the largest numbers were caught in June and July samples, e.g. 46 individuals in a sample on 18 June 2005 and 43 in a 13 July 2002 sample. This agrees well with the 12-m suction trapping results of Greenslade et al. (2020) who also recorded a large peak in June-July. Greenslade et al. also recorded small peaks of Cacopsylla melanoneura / affinis in February-early April and in the late autumn, i.e. outside the period of our aerial sampling. Nearly all the Cacopsylla species caught by us $-C$. melanoneura / affinis, C. brunneipennis (Edwards, 1896) / pulchra (Zetterstedt, 1840) and $C$. pruni - overwinter as reproductively-diapausing adults largely on conifers or evergreen shrubs (Hodkinson, 2009) (see Appendix). Some authors have found that Cacopsylla spp. do not simply relocate to nearby conifers, but tend to migrate further afield to overwinter on conifers in mountainous areas (Čermák \& Lauterer, 2008; Thébaud et al., 2009). Therefore, it is highly likely that the early season movement detected by Greenslade $e t$ al. represents a migration from overwintering sites to host plants on which juvenile development can ensue - Hodkinson (1972) mentions that even in the cool environment of the northern Pennines psyllids had left winter shelters in pine trees by May. Subsequently, as these Cacopsylla are univoltine (Hodkinson, 2009), the large summer movement recorded both by Greenslade et al. and the present study would appear to be a migration to the wintering sites by the new generation of adults. Although it might seem rather early for such a movement, Thébaud et al. (2009) in south-eastern France showed that $C$. pruni migrated to conifers in June, and then spent 8 months there. Also, monitoring of overwintering sites in Moravia (Czech Republic) revealed that the Cacopsylla spp. movement can be as early as late May and June (Čermák \& Lauterer, 2008). The adaptive reason suggested for this timing was that convective upcurrents necessary for fairly long-range migration would be more likely in June-August; migration later in the year (September-November) would restrict the migrants to shorter distance movements (Čermák \& Lauterer, 2008). However, some psyllids show peak flight activity in autumn, e.g. Aphalara spp. (see below), or even as late as November and December, e.g. T. remota in the $12.2 \mathrm{~m}$ suction traps (Greenslade et al., 2020). 
Conceivably, in these circumstances, upward movement may be less dependent on convective updrafts and more on self-propelled ascent.

Trioza urticae, the second most common species in our samples, was caught only in June, which coincides with the large mid-summer peak recorded by Greenslade et al. (2020). The species is multivoltine with at least three generations per year in the UK (Hodkinson \& White, 1979), but separate movement events associated with the generations are not evident from the suction-trap record (Greenslade et al. 2020). The small peak in NovemberDecember presumably represents a late $T$. urticae migration to winter shelter locations. Weidel (2008) caught two T. urticae, at heights of 150 and $640 \mathrm{~m}$ respectively, in October.

The few Aphalara spp. in our aerial samples were from the 'Aphalara calthae group' of species sensu Burckhardt \& Lauterer (1997). There are five species known from Britain in this group at the time of publication (Greenslade et al. 2020). These Aphalara spp. seemed to show a different pattern to the previously-mentioned species, being caught only in late August and September. Aerial samples were not taken later in the season, but the $12.2 \mathrm{~m}$ suction trapping in 2015 at three sites in England produced the following numbers of the $A$. calthae group: July - 1; August - 4; September - 6; October - 6 and November - 3 (A.F.C. Greenslade, unpublished). This picture of autumn movement is strongly reinforced by Freeman (1945) who caught large numbers of an Aphalara sp. in September in his higherlevel traps (54 and $84 \mathrm{~m}$ ) (see Table 2). Lastly, we note that Weidel $(2008,2010)$ caught 6 Aphalara crispicola Ossiannilsson (now considered a synonym of Aphalara purpurascens (Hartig, 1841)) between 100 and 1520 m over northern Germany, again in August, September and October.

Aphalara spp. have 1-2 generations per year (A. polygoni Foerster, 1848 is bivoltine, for example) (Hodkinson, 2009), and as Aphalara "are never found on their true host plant during the winter" (Hodkinson \& White, 1979), it seems likely that flights in the autumn represent movement of reproductively-diapausing adults to their winter shelters on conifers or evergreen shrubs (Hodkinson, 2009).

Generally, the phenology of common British psyllid species, as documented by $12.2 \mathrm{~m}$ suction traps, does seem to be reflected in our catches at $200 \mathrm{~m}$ above ground. This supports the view that the suction trap network is detecting psyllid migration events and indicates that windborne movement may transport psyllids over significant distances.

\section{Conclusion}

The present report forms a companion paper to Greenslade et al. (2020), who sampled psyllids across Britain at a height $12.2 \mathrm{~m}$ above ground, and mirrors many of their findings. This validates the view that the nationwide suction-trap network is suitable for monitoring psyllid movement in the UK, and offers the opportunity for testing for important disease agents, such as 'Candidatus Phytoplasma prunorum' carried by $C$. pruni. Together the papers provide evidence for the substantial migration capabilities of certain psyllid species over distances of at least several kilometres, and probably tens of kilometres. These studies, although preliminary, have still revealed definite patterns in the syndrome of migratory behaviour in some British Psylloidea, and hopefully will provide a basis for further research.

\section{Acknowledgements}

We are grateful to the Director of the Meteorological Research Unit (UK Meteorological Office) for permission to operate our kytoon within the official aircraft exclusion zone at Cardington, and thank Mr D. Bamber and other Met Office staff for their advice on various administrative and practical aspects of the balloon flying operations. Special thanks are due to Mr A.D. Smith (formerly at Rothamsted) for invaluable help in organising the aerial sampling programmes. S. Dunn, R. Selby, D. Sivell, E.T. Smith and C.R. Wood assisted with 
the balloon handling and sorting of the aerial catches during particular seasons of field work. The Rothamsted Insect Survey, a National Capability, is funded by the Biotechnology and Biological Sciences Research Council under the Core Capability Grant BBS/E/C/000J0200.

\section{References}

Berland, L. 1935. Premier résultats de mes recherches en avion sur la faune et la flore atmosphériques. Annales de la Société Entomologique de France 104: 73-96.

Berry, R. E. \& Taylor, L. R. 1968. High-altitude migration of aphids in maritime and continental climates. Journal of Animal Ecology 37: 713-722.

Burckhardt, D. \& Lauterer, P. 1997. Systematics and biology of the Aphalara exilis (Weber \& Mohr) species assemblage (Hemiptera: Psyllidae). Entomologica Scandinavica 28: 271-305.

Čermák, V. \& Lauterer, P. 2008. Overwintering of psyllids in South Moravia (Czech Republic) with respect to the vectors of the apple proliferation cluster phytoplasmas. Bulletin of Insectology 61: 147-148.

Chapman, J. W., Reynolds, D. R., Smith, A. D., Smith, E. T. \& Woiwod, I. P. 2004. An aerial netting study of insects migrating at high altitude over England. Bulletin of Entomological Research 94:123-136.

Freeman, J. A. 1939. Studies in the distribution of insects by aerial currents. A contribution to the study of windborne insects with special reference to vertical distribution and dispersal. PhD Thesis, University College, Hull, UK.

Freeman, J. A. 1945. Studies in the distribution of insects by aerial currents. The insect population of the air from ground level to 300 feet. Journal of Animal Ecology 14: 128154.

Glick, P. A. 1939. The distribution of insects, spiders and mites in the air. Technical Bulletin No. 673. Washington DC, United States Department of Agriculture.

Glick, P. A. 1960. Collecting insects by airplane, with special reference to dispersal of the potato leafhopper. Technical Bulletin No. 1222, Washington DC, United States Department of Agriculture.

Glick, P. A. \& Noble, L. W. 1961. Airborne movement of the pink bollworm and other arthropods. Technical Bulletin No. 1255.Washington DC, United States Department of Agriculture.

Greenslade, A. F. C., Carnegie, M., Ouvrard, D., Sjölund, M. J., Highet, F., Sigvald, R., Kenyon, D. M. \& Bell, J.R. 2020. Aerial psyllid (Hemiptera: Psylloidea) detection and monitoring using suction traps in Britain: population observations, new species found and a revised British checklist. Entomologist's Gazette 71(3): 151-163.

Hardy, A. C. \& Cheng, L. 1986. Studies in the distribution of insects by aerial currents. III. Insect drift over the sea. Ecological Entomology 11, 283-290.

Hardy, A. C. \& Milne, P. S. 1938. Studies in the distribution of insects by aerial currents. Experiments in aerial tow-netting from kites. Journal of Animal Ecology 7, 199-229.

Harrell, J. C. \& Yoshimoto, C. M. 1964. Trapping of air-borne insects on ships on the Pacific, Part 5. Pacific Insects 6(2): 274-82.

Hodkinson, I. D. 1972. Long range dispersal of certain species of Psyllidae in the Northern Pennines. Entomologist's Monthly Magazine 108: 21-22.

Hodkinson, I. D. 2009. Life cycle variation and adaptation in jumping plant lice (Insecta: Hemiptera: Psylloidea): a global synthesis. Journal of Natural History 43: 65-179.

Hodkinson, I. D. \& White, I. M. 1979. Homoptera: Psylloidea. Handbooks for the Identification of British Insects, vol. II, part 5 (a). Royal Entomological Society of London, London. 
Holzapfel, E. P. \& Harrell, J. C. 1968. Transoceanic dispersal studies of insects. Pacific Insects 10: 115-153.

Johnson, C. G. 1969. Migration and dispersal of insects by flight. Methuen, London, xxii + $766 \mathrm{pp}$

Lewis, T. \& Taylor, L. R. 1965. Diurnal periodicity of flight by insects. Transactions of the Royal Entomological Society of London 116: 393-479.

Peck, S. B. 1994. Aerial dispersal of insects between and to islands in the Galápagos Archipelago, Ecuador. Annals of the Entomological Society of America 87: 218-224.

Percy, D. M. 2014. Psyllids of Economic Importance. https://www.psyllids.org/psyllidsPests.htm . Accessed 1 November 2020.

Reynolds, D.R., Nau, B.S. \& Chapman, J.W. 2013. High-altitude migration of Heteroptera in Britain. European Journal of Entomology 110: 483-492.

Reynolds, D. R., Chapman, J. W. \& Stewart, A. J. A. 2017. Windborne migration of Auchenorrhyncha (Hemiptera) over Britain. European Journal of Entomology 114: 554 564.

Taylor, L. R. 1974. Monitoring change in the distribution and abundance of insects. Rothamsted Experimental Station Report for 1973, Part 2: 202-239. https://doi.org/10.23637/ERADOC-1-34639

Thébaud, G., Yvon, M., Alary, R., Sauvion, N. \& Labonne, G. 2009. Efficient transmission of 'Candidatus Phytoplasma prunorum' is delayed by eight months due to a long latency in its host-alternating vector. Phytopathology 99: 265-273.

Wainwright, C.E., Stepanian, P.M., Reynolds, D.R. \& Reynolds, A.M. 2017. The movement of small insects in the convective boundary layer: linking patterns to processes. Scientific Reports 7: article 5438.

Wainwright, C. E., Reynolds, D. R. \& Reynolds, A. M. 2020. Linking small-scale flight manoeuvers and density profiles to the vertical movement of insects in the nocturnal stable boundary layer. Scientific Reports 10: article 1019.

Weidel, H. 2008. Die Verteilung des Aeroplanktons über Schleswig-Holstein. Doctoral Dissertation, Faculty of Mathematics and Natural Sciences, Christian-AlbrechtsUniversity, Kiel, Germany. http://d-nb.info/1019553197/34

Weidel, H. 2010. Das Aeroplankton in der Norddeutschen Tiefebene über SchleswigHolstein. Faunistisch-Ökologische Mitteilungen 9(3/4): 111-129.

White, T. C. R. 1970. Airborne arthropods collected in South Australia with a drogue-net towed by a light aircraft. Pacific Insects 12(2): 251-59.

White, T. C. R. 1973. Aerial dispersal of adult Cardiaspina densitexta (Homoptera, Psyllidae) Transactions of the Royal Society of South Australia 97: 29-31.

White, T. C. R. 1974. Semi-quantitative sampling of terrestrial arthropods occurring in the air over South Australia. Pacific Insects 16(1): 1-9. 


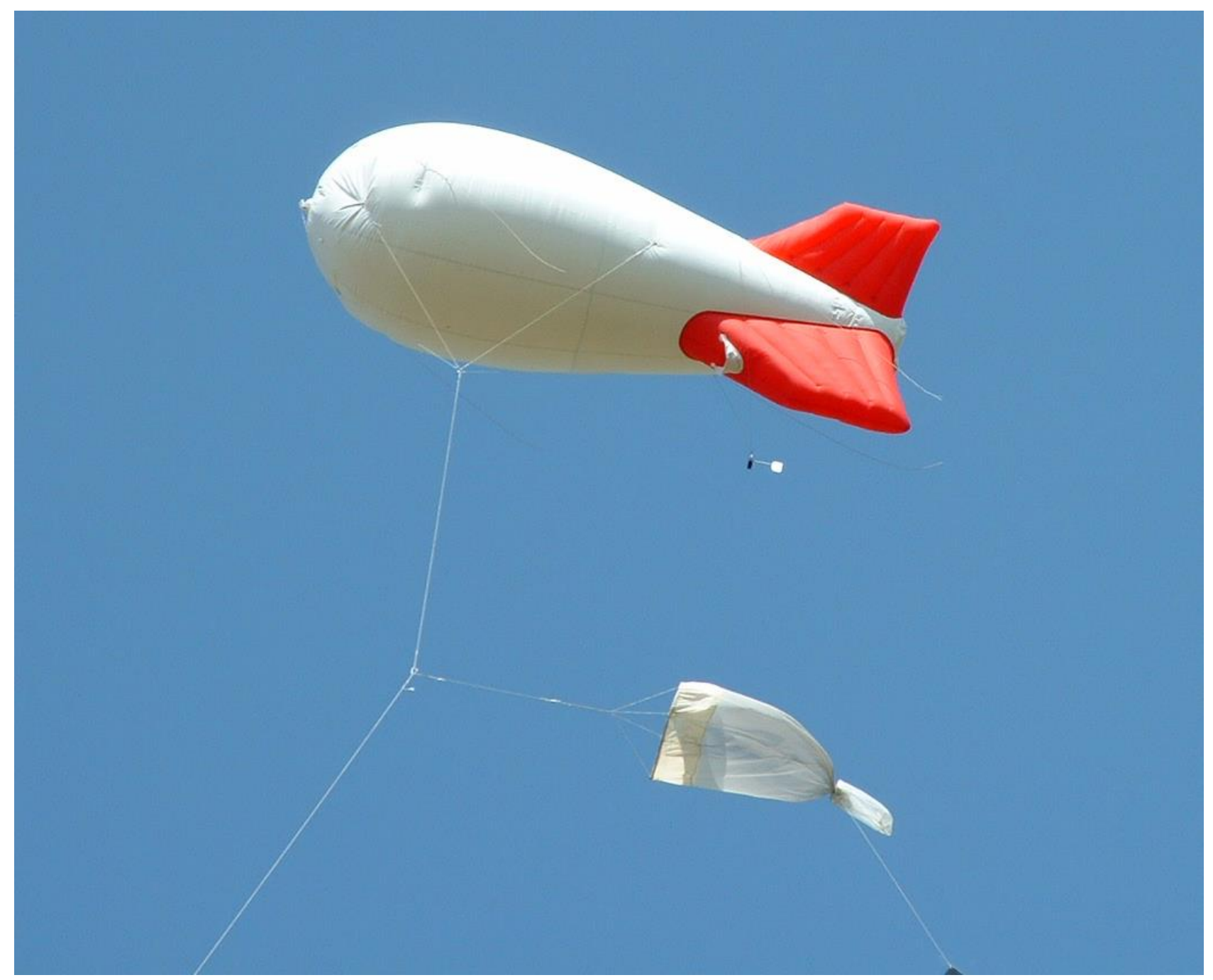

Fig. 1. Sampling insects at $200 \mathrm{~m}$ above ground by means of a net attached to the tethering line of a 6-m long kytoon. The detachable bag at the end of the net has been closed-off, prior to winching down of the kytoon to ground level and recovery of the sample. A wind-run meter can be seen suspended below the kytoon tail. 
Table 1. Psylloidea caught at high altitude (ca. $200 \mathrm{~m}$ a.g.l) at Cardington, Bedfordshire, UK, 1999-2007.

\begin{tabular}{|c|c|c|c|c|c|c|c|c|c|c|}
\hline & Year & 1999 & 2000 & 2002 & 2003 & 2004 & 2005 & 2006 & 2007 & Total \\
\hline & Sampling month(s) & July & July & July & $\begin{array}{l}\text { August } \\
\text {-Sept. }\end{array}$ & July & $\begin{array}{l}\text { June } \\
\text {-July }\end{array}$ & $\begin{array}{l}\text { August } \\
\text {-Sept. }\end{array}$ & $\begin{array}{l}\text { May- } \\
\text { July }\end{array}$ & \\
\hline & Total wind-run $(\mathrm{km}) \dagger$ & 2847.2 & 2524.0 & 2273.0 & 2922.1 & 2610.0 & 3262.0 & 1370.0 & 2188.0 & \\
\hline Family & Species & & & & & & & & & \\
\hline Aphalaridae & Aphalara spp. & & & & 2 & & & 3 & & 5 \\
\hline Liviidae & Psyllopsis fraxinicola (Foerster) & & 1 & & & & & & & $\mathbf{1}$ \\
\hline \multirow[t]{3}{*}{ Psyllidae } & $\begin{array}{l}\text { Cacopsylla melanoneura (Foerster) } \\
\text { affinis (Löw) }\end{array}$ & 18 & 31 & 101 & & 19 & 232 & 2 & 48 & 451 \\
\hline & $\begin{array}{l}\text { Cacopsylla pulchra (Zetterstedt) / } \\
\text { brunneipennis (Edwards) }\end{array}$ & & & 1 & & & & & 3 & 4 \\
\hline & Cacopsylla pruni (Scopoli) & & 1 & & & 3 & & & 1 & 5 \\
\hline \multirow[t]{3}{*}{ Triozidae } & Trioza chenopodii Reuter & & & & & 1 & & & & 1 \\
\hline & Trioza galii Foerster & & & 2 & & & & & & 2 \\
\hline & Trioza urticae (L.) & & & & & & 17 & & & 17 \\
\hline $\begin{array}{l}\text { Unidentified Psylloidea } \\
\text { (missing samples) }\end{array}$ & & & & & & 2 & 2 & & & 4 \\
\hline Total & & 18 & 33 & 104 & 2 & 25 & 251 & 5 & 52 & 490 \\
\hline $\begin{array}{l}\text { Mean density } \\
\left(\text { numbers } / 10^{4} \mathrm{cu} . \mathrm{m}^{3}\right)\end{array}$ & & 0.69 & 1.21 & 1.72 & 0.34 & 0.56 & 2.20 & 0.26 & 0.84 & \\
\hline
\end{tabular}

$\uparrow$ Total wind-run for all sampling periods in that season (provides a measure of sampling intensity). 
Table 2. Comparison of catches of Psylloidea obtained during some aerial trapping studies over England.

\begin{tabular}{|c|c|c|c|c|c|c|c|c|}
\hline \multicolumn{2}{|l|}{ Study reference } & \multicolumn{2}{|c|}{$\begin{array}{c}\text { Freeman, 1939, } \\
1945\end{array}$} & \multicolumn{2}{|c|}{$\begin{array}{c}\text { Hardy \& Milne, } \\
1938\end{array}$} & \multicolumn{2}{|c|}{ Present study } & Totals \\
\hline \multicolumn{2}{|l|}{ Sampling location } & \multicolumn{2}{|c|}{$\begin{array}{l}\text { Tetney, near } \\
\text { Grimsby }\end{array}$} & \multicolumn{2}{|c|}{$\begin{array}{c}\text { Hull, Thorpeness } \\
\text { (Suffolk), and near } \\
\text { Dover } \\
\end{array}$} & \multicolumn{2}{|c|}{$\begin{array}{l}\text { Cardington, } \\
\text { Bedfordshire }\end{array}$} & \\
\hline \multicolumn{2}{|l|}{ Year(s) } & \multicolumn{2}{|c|}{1934,1935} & \multicolumn{2}{|c|}{$1932-1933$} & \multicolumn{2}{|c|}{$\begin{array}{c}1999,2000,2002- \\
2007 \\
\end{array}$} & \\
\hline \multicolumn{2}{|l|}{ Sampling Period } & \multicolumn{2}{|c|}{ May - September } & \multicolumn{2}{|c|}{ June - October } & \multicolumn{2}{|c|}{$\begin{array}{c}\text { May - early } \\
\text { September }\end{array}$} & \\
\hline \multicolumn{2}{|l|}{ Time of sampling } & \multicolumn{2}{|c|}{ Day only } & \multicolumn{2}{|c|}{ Day only } & \multicolumn{2}{|c|}{ Day \& night } & \\
\hline \multicolumn{2}{|l|}{ Height of sampling } & \multicolumn{2}{|c|}{54 and $84 \mathrm{~m}$ only* } & \multicolumn{2}{|c|}{$60-610 \mathrm{~m}$} & \multicolumn{2}{|c|}{ c. $200 \mathrm{~m}$} & \\
\hline Psylloidea family \& species & $\begin{array}{l}\text { Species name in Freeman, or } \\
\text { Hardy \& Milne } \\
\text { (if different) }\end{array}$ & Number & $\%$ & Number & $\%$ & Number & $\%$ & \\
\hline \multicolumn{9}{|l|}{ Aphalaridae } \\
\hline Aphalara spp. & & 2 & 1.07 & & & 5 & 1.02 & 7 \\
\hline$"$ & Aphalara calthae $\dagger$ & 173 & 92.51 & 6 & 75 & & & 179 \\
\hline \multicolumn{9}{|l|}{ Liviidae } \\
\hline Psyllopsis fraxinicola (Foerster) & & & & & & 1 & 0.20 & 1 \\
\hline \multicolumn{9}{|l|}{ Psyllidae } \\
\hline Psylla sp. & & 2 & 1.07 & & & & & 2 \\
\hline Cacopsylla mali (Schmidberger) & Psylla mali & 2 & 1.07 & & & & & 2 \\
\hline Cacopsylla melanoneura (Foerster) / affinis (Löw) & & & & & & 451 & 92.04 & 451 \\
\hline Cacopsylla pulchra (Zetterstedt) / brunneipennis (Edwards) & & & & & & 4 & 0.82 & 4 \\
\hline Cacopsylla pulchra (Zetterstedt) & Psylla nigrita & & & 2 & 25 & & & 2 \\
\hline Cacopsylla pruni (Scopoli) & & & & & & 5 & 1.02 & 5 \\
\hline \multicolumn{9}{|l|}{ Triozidae } \\
\hline Trioza $\mathrm{sp}$. & Spanioza sp. & 2 & 1.07 & & & & & 2 \\
\hline
\end{tabular}




\begin{tabular}{|c|c|c|c|c|c|c|c|c|}
\hline Trioza chenopodii Reuter & Spanioza atriplicis & 4 & 2.14 & & & 1 & 0.20 & 5 \\
\hline Trioza galii Foerster & & 1 & 0.53 & & & 2 & 0.41 & 3 \\
\hline Trioza urticae (L.) & & & & & & 17 & 3.47 & 17 \\
\hline Unidentified Psylloidea & & 1 & 0.53 & & & 4 & 0.82 & 5 \\
\hline Total Psylloidea & & 187 & 100 & 8 & 100 & 490 & 100 & 685 \\
\hline Total insects and \% Psylloidea & & 7748 & 2.41 & 839 & 0.95 & 17752 & 2.76 & \\
\hline
\end{tabular}

*Freeman's samples taken at his lowest height ( $3 \mathrm{~m}$ above ground) were omitted.

$\dagger$ Aphalara calthae is not on recent checklists of psyllids in Britain (e.g. Greenslade et al. 2020) but these individuals probably belong to the 'Aphalara calthae group' of species. 


\section{Appendix}

Host plant (on which the species breeds), voltinism, overwintering stage and location of some psyllid species caught at altitude (life-history information from Hodkinson, 2009). $\mathbf{C}=$ conifers and evergreen shrubs

\begin{tabular}{|l|l|l|l|l|}
\hline Species & Host plant & Voltinism & $\begin{array}{l}\text { Overwintering } \\
\text { stage }\end{array}$ & $\begin{array}{l}\text { Overwintering } \\
\text { location }\end{array}$ \\
\hline Cacopsylla melanoneura & Crataegus, Malus & 1 & Adult & C \\
\hline Cacopsylla affinis & Stellaria & $1 ?$ & Adult & C \\
\hline Cacopsylla pruni & Prunus & 1 & Adult & C \\
\hline Cacopsylla brunneipennis & Salix & 1 & Adult & C \\
\hline Cacopsylla mali & Malus & 1 & Egg & on host shoots \\
\hline Cacopsylla pulchra & Salix & 1 & Adult & C \\
\hline & & & & \\
\hline Aphalara spp. & & $1-2$. & Adult & C \\
\hline & & 2 in polygoni & & \\
\hline Trioza urticae & Urtica & $1-4$ & Adult & $\begin{array}{l}\text { C + grass } \\
\text { tussocks near } \\
\text { host }\end{array}$ \\
\hline $\begin{array}{l}\text { Trioza chenopodii } \\
\text { (seasonally polymorphic } * \text { ) }\end{array}$ & $\begin{array}{l}\text { Chenopodium, Atriplex, } \\
\text { Hrioza galii }\end{array}$ & $2-5$ & Adult & on host shoots \\
\hline & Galium, Asperula & $1+?$ & Adult & C \& leaf litter \\
\hline Psyllopsis fraxinicola & Fraxinus & & & \\
\hline
\end{tabular}

* Has a long-winged summer form and an autumn-winter form with shorter, broader wings. 